\title{
Evaluation of Heirloom and Commercial Cultivars of Small Grains under Low Input Organic Systems
}

\section{Tejendra Chapagain*, Andrew Riseman}

Faculty of Land and Food Systems, The University of British Columbia, Vancouver, Canada.

Email: "tejchapagain@yahoo.com

Received January $12^{\text {th }}, 2012$; revised February $17^{\text {th }}, 2012$; accepted February $28^{\text {th }}$, 2012

\begin{abstract}
A cultivar trial, including commercial and heirloom cultivars of major cereals and grain legumes was conducted in Vancouver, BC, under low input organic conditions. We assessed 19 wheat (6 commercial and 13 heirloom), 17 barley (8 commercial and 9 heirloom), 5 pea, 5 favabean, 5 kidneybean, 2 lentil, and 2 soyabean cultivars for plant performance metrics, and their potential in a small grain:legume intercropping system. Heirloom wheat cultivars showed notable response in a number of parameters including late maturity, taller plants, greatest number of spikes per $\mathrm{m}^{2}$, longest spike, highest number of seed per spike, greater seed weight to volume ratio, and resistance to stripe rust compared with commercial cultivars. For the heirloom-type, 6 of 14 wheat cultivars, (i.e., "Reward”, "Glenn”, “Cerebs", "Red Bobs", "Sounders" and "Black Bearded") produced yields comparable to the commercial cultivars (i.e., nearly $5 \mathrm{t} / \mathrm{h}$ or higher). Also, heirloom cultivars typically contained higher protein levels most suitable for baking and blending purposes with "Einkorn" displaying the highest level (16.2\%). Heirloom and commercial barley cultivars did not differ significantly with respect to plant height, spike length, and seed weight to volume ratio. However, a number of heirloom cultivars (e.g., “Jet”, "Dolma”, “Andie” and "Himalayan”) displayed greater responses on earliness, number of spikes per $\mathrm{m}^{2}$, grain yield, protein content and seed weight to volume ratio. Pea and lentil yielded lower than the national average under trial conditions. However, heirloom peas "Corgi", "De Grace”, "Snowbird”, and "Golden” were earlier compared to the commercial cultivar "Reward". All kidney bean cultivars yielded $~ 3 \mathrm{t} / \mathrm{h}$ with the highest yield from "Red Kidney" (3.8 $\mathrm{t} / \mathrm{h})$. Fava and soyabean appeared as promising crops as the cultivars produced good growth and yields. Neither lentil ("Crimson" and "Essex") produced satisfactory responses though they had excellent vegetative growth and flowered. Therefore, significant variation was observed including several heirloom cultivars displayed great potential in terms of yield, protein content, and disease resistance and that specific cultivars were better suited for an intercropping system.
\end{abstract}

Keywords: Commercial and Heirloom Cultivars; Hulled and Hulless; 2-Row and 6-Row; Intercropping

\section{Introduction}

Annual small grains, particularly wheat and barley, are an important part of the cropping systems used in the Canadian prairies [1]. Wheat is the principal cereal grain grown in Canada with production of 24 million tones on over 11 million ha [2,3]. The majority of Canada's wheat is produced in the Prairie Provinces of Alberta, Saskatchewan, and Manitoba with some production in parts of British Columbia. The majority is spring wheat (including durum wheat), accounting for $94 \%$ of total production [3]; the remaining $6 \%$ is mostly winter wheat being produced primarily in southern Ontario. In recent decades, crops such as barley, canola, and grain-legumes have witnessed increased production in areas with sufficient precipitation.

${ }^{*}$ Corresponding author.
Canada has over 3500 organic farms on almost 480,000 ha, which is about $1.5 \%$ of the total agricultural area in the country [4]. Nearly 65\% Canada's organic farms reported the production of field crops including wheat and barley and to a lesser extent, legumes and oilseed crops $[5,6]$. The Canadian market comprises only $6.5 \%$ of the North American market for organic food and drink; however, the growth in demand for such products is estimated at 15\% - 20\% per year since the late 1990s [7].

One of the challenges in meeting the increasing demand for organic small grains is attributed to the lower yields in organically managed fields than those of conventionally grown grain crops [8-11]. Studies in Australia reported that organic wheat grain yields were $21 \%$ $31 \%$ lower [10] to less than half [11] of conventional grain yields. In Canada, where research relating to or- 
ganic grain production to date is limited, Entz et al. [9] found that wheat, oat and barley yields were $23 \%-27 \%$ lower on organic farms; however, maximum yields were higher on organic farms than long-term conventional averages, highlighting the potential for successful organic grain production [12]. Competition from weeds [9], nutrient deficiency $[9,13]$, and some cultural and climatic factors $[10,14]$ can play a role in reducing organic crop yields.

The Vancouver Island region, which also encompasses most of the islands of the Georgia Strait, has mild temperatures suitable for the planting of cereals as a spring crop. Spring cereals have their nitrogen demand more aligned with soil nitrogen cycles. However, their grain filling is likely to be shorter with a greater probability of rainy conditions spoiling the harvest or requiring earlier harvest and drying to achieve adequate quality [15]. These conditions coupled with the availability of few relatively poor quality spring wheat cultivars in the past has given spring grain production a poor reputation among farmers in south coastal British Columbia [16].

Nevertheless, a constant supply of recently developed or new to the area cultivars of cereals and grain legumes is available these days to Lower Mainland growers in British Columbia (BC). Also, heirloom cultivars of wheat and barley that are supposed to be high yielding and more resistance to the biotic and abiotic stresses have also been reported. There exists tremendous genetic diversity in both wheat and barley cultivar collections, including heritage cultivars (pre 1960 production), that grow well without high chemical inputs and that may be well suited for sustainable, low-input production [17]. However, decisions to grow a new cultivar are rarely from information based on local growing conditions. Therefore, a cultivar trial, including commercial and heirloom cultivars of major cereals (wheat and barley) and legumes (pea, lentil, soyabean, favabean and kidneybean) was conducted at The Centre for Sustainable
Food Systems-UBC Farm, University of British Columbia (UBC), Vancouver, BC, during the 2010 season. The primary objective of this research was to provide local farmers, extension personnel, and consultants with the necessary information to make well informed decisions as to which small grain cultivars to grow. The following specific objectives were identified:

- $\quad$ To compare the plant performance (i.e., yield, 1000 seed weight, protein content, days to harvest, harvest index, etc.) of commercial and heirloom cultivars of wheat, barley, pea and lentil and other legumes grown under "organic" standards at the UBC Farm;

- To assess disease incidence and severity among cultivars grown under "organic" standards at the UBC Farm.

\section{Materials and Methods}

\subsection{Study Site}

This study was conducted at the Centre for Sustainable Food Systems at UBC Farm in Vancouver, BC, during 2010 cropping season (May to September). The experimental site is situated at $49^{\circ} 15^{\prime} 3^{\prime \prime} \mathrm{N}$ and $123^{\circ} 14^{\prime} 20^{\prime \prime} \mathrm{W}$, at an altitude of $100 \mathrm{~m}$ above mean sea level. Research was conducted under natural climatic conditions.

Hydro-meteorological description of the study area: Climatic data are summarized for the experimental site during the spring-summer season (June to September) of 2010 (Table 1). Average day-time temperature over the cropping season was $17.10^{\circ} \mathrm{C}$, with the warmest days in August, whereas the average night-time temperature was $14.60^{\circ} \mathrm{C}$. The average daily soil temperature at $10-\mathrm{cm}$ and $20-\mathrm{cm}$ depth was $18.90^{\circ} \mathrm{C}$ and $18.60^{\circ} \mathrm{C}$, respectively. Monthly average of solar radiation reaching the soil surface was $590.3 \mathrm{~W} / \mathrm{m}^{2}$. The monthly precipitation average was $61.5 \mathrm{~mm}$ with July receiving the least rain and September receiving the most. Total precipitation during

Table 1. Meteorological data during the cropping season of 2010 at UBC farm, Vancouver, Canada (Source: Totem Park weather station, UBC).

\begin{tabular}{|c|c|c|c|c|c|c|c|c|c|c|c|c|c|c|}
\hline \multirow{3}{*}{ Month } & \multicolumn{3}{|c|}{$\begin{array}{c}\text { Mean Air } \\
\text { Temperature }\left({ }^{\circ} \mathrm{C}\right)\end{array}$} & \multicolumn{6}{|c|}{$\begin{array}{l}\text { Mean Soil Temperature }\left({ }^{\circ} \mathrm{C}\right) \\
\text { at Different Depth }\end{array}$} & \multicolumn{3}{|c|}{$\begin{array}{c}\text { Relative } \\
\text { Humidity (\%) }\end{array}$} & \multirow{3}{*}{$\begin{array}{l}\text { Solar Energy } \\
\left(\mathrm{W} / \mathrm{m}^{2}\right)\end{array}$} & \multirow{3}{*}{$\begin{array}{l}\text { Total Rainfall } \\
\quad(\mathrm{mm})\end{array}$} \\
\hline & \multirow{2}{*}{ Day } & \multirow{2}{*}{ Night } & \multirow{2}{*}{24 hours - } & \multicolumn{3}{|c|}{$10-\mathrm{cm}$} & \multicolumn{3}{|c|}{ 20-cm } & \multirow{2}{*}{ - Day } & \multirow{2}{*}{ Night } & \multirow{2}{*}{24 Hours } & & \\
\hline & & & & Day & Night & 24 Hours & Day & Night & 24 Hours & & & & & \\
\hline June & $15.1(21)$ & 12.8 & 13.9 & 18.2 & 18.6 & 18.4 & 17.6 & 18.1 & 17.9 & 76.3 & 83.2 & 79.7 & 569.4 (1419) & 57.4 \\
\hline July & $18.6(28.9)$ & 15.8 & 17.4 & 20.3 & 21 & 20.6 & 19.6 & 20.3 & 19.9 & 69.7 & 77.7 & 73.2 & 778.5 (1424) & 6.6 \\
\hline August & $18.9(30)$ & 16.1 & 17.6 & 19 & 19.5 & 19.3 & 18.7 & 19.3 & 19 & 70.1 & 78.2 & 73.9 & 602.7 (1345) & 61.2 \\
\hline September & r 15.7 (22.6) & 13.8 & 14.7 & 17.3 & 17.7 & 17.5 & 17.3 & 17.7 & 17.5 & 79.7 & 87.9 & 83.8 & 410.5 (1188) & 120.6 \\
\hline Average & 17.1 & 14.6 & 15.9 & 18.7 & 19.2 & 18.9 & 18.3 & 18.9 & 18.6 & 73.9 & 81.8 & 77.7 & 590.3 & 61.5 \\
\hline
\end{tabular}

Figures in parenthesis under mean air temperature column indicate the highest temperature in respective months; Figures in parenthesis under solar energy column indicate the highest intensity of solar radiation on the earth surface in respective months. 
June to September was $245.8 \mathrm{~mm}$. The $24 \mathrm{~h}$ average for relative humidity (RH) ranged from 73.2 to 83.8 in July and September, respectively.

Soil and site description: Four random composite soil samples were collected at the time of plot establishment to characterize soil fertility (i.e., $\mathrm{pH}, \mathrm{EC}$, total $\mathrm{N}$, and available $\mathrm{P}, \mathrm{K}, \mathrm{Ca}, \mathrm{Mg}, \mathrm{Cu}, \mathrm{Zn}, \mathrm{Fe}, \mathrm{Mn}$ and $\mathrm{B}$ ). The average values are listed (Table 2). The soil is a coarse textured sandy loam of the Bose series [18] with low to moderate fertility. Soil was fairly homogeneous across the test site. The site was not used for grain production in prior years but was a designated area for seasonal vegetable cultivation. The land has been managed under organic guidelines for more than the 10 years and therefore does not include any prohibited chemicals/substances.

\subsection{Experimental Details}

Commercial and heirloom cultivars of wheat, barley, pea, lentil, fava bean, kidney bean, and soyabean were sourced from farmers in BC, Agriculture and Agri-Food Canada, and various states throughout the USA (i.e., Alaska, California, Colorado, Connecticut, Idaho, Maine, Oregon, Vermont, Wisconsin, and Washington). Commercial and heirloom cultivar descriptions and planting details are listed (Tables 3 and $\mathbf{4}$ ).

All cultivars listed were provided with the same level of management. Seeds were cleaned as necessary, counted (except for commercial cultivars for which test weights were provided), and weighed to calculate the appropriate seeding rate. Wheat and barley cultivars were sown using a hand seeder (Jang Clean Hand Seeder, Jang Automation Co. Ltd., Cheongju-city, South Korea) with adjustable sprockets (Front: 11, Rear: 14), and seed plates (AA-6 for wheat and barley, G-12 for pea) whereas grain legumes were planted by hand along the line using the seed rate as specified.

Spring cereals were planted at $12 \mathrm{~cm}$ spacing in late May (28-30 May, 2010) targeting 280 - 300 viable plants $/ \mathrm{m}^{2}$. Therefore, assuming a $>80 \%$ germination rate, a seed density of $350 \mathrm{seed} / \mathrm{m}^{2}$ for wheat and barley cultivars was used. Our seed density for pea, lentil, favabean, kidney bean and soyabean was 66, 200, 33, 33 and 33 seed $/ \mathrm{m}^{2}$, respectively, targeting $60,160,30,30$ and 30 viable plants $/ \mathrm{m}^{2}$. Both the commercial and heirloom cultivar plots measured $9 \mathrm{~m} \times 3 \mathrm{~m}$, which was subdivided into three plots of $3 \mathrm{~m} \times 3 \mathrm{~m}$ that resembled three replications in randomized complete block design (RCBD). Data were collected from 2 different areas of $0.5 \mathrm{~m}^{2}$ within each plot and averaged, serving as one sample.

Sowing depth varied with seed size and ranged from 3 $5 \mathrm{~cm}$ (e.g., 3 - $4 \mathrm{~cm}$ for small seeds like wheat, barley, and lentil; $4-5 \mathrm{~cm}$ for larger seeds like favabean and kidney bean). Plot layout was alternated between wheat, barley and legumes to minimize out-crossing between cultivars. Plots were equipped with a sprinkle irrigation system for timely irrigation during long dry periods. No external fertilizers, pesticides or fungicides were used on test plots throughout the growing season.

\subsection{Data Collection and Analysis}

Plant-based parameters: Data were recorded for plant height (from soil surface to the tip of apical leaf), number of effective tillers (heads) per unit area $\left(\mathrm{m}^{2}\right)$, days to harvest, spike length, seed per spike, grain yield $\left(\mathrm{g} \cdot \mathrm{m}^{-2}\right.$ and $t \cdot h^{-1}$, respectively), 1000 seed weight, harvest index [HI, defined as a ratio of economical yield (grain yield) to the total plant mass (grain yield + plant biomass)], and seed weight to volume ratio. Chlorophyll concentration index (CCI) was measured using handheld chlorophyll meter (Model CCM 200 plus, Opti-Sciences Inc., New Hampshire, USA) on the flag leaf and the 3rd leaf during early growth stage (30 DAS). Spike color was a determinant of maturity and considered ready for harvest when spikelets were straw-colored and $80 \%$ of the grains of the spike were in the hard-dough stage. The plots were sampled by harvesting the above ground biomass within each randomly selected $0.5 \times 0.5 \mathrm{~m}^{2}$ subplot, leaving 10 $\mathrm{cm}$ stubble. Crop material was dried at $60^{\circ} \mathrm{C}$ and threshed. Grain was ground to $<0.6 \mathrm{~mm}$ and analyzed for total nitrogen, according to the Kjeldahl method (Appendix 2) and converted to crude protein levels $(\% \mathrm{~N} \times 5.7$ for wheat, and $\% \mathrm{~N} \times 5.8$ for barley). Each sample was replicated thrice. Grain yield, test weight (thousand grain weight) and protein concentrations are expressed at $12.5 \%$

Table 2. Soil properties ${ }^{1}$ at site (prior to sowing).

\begin{tabular}{|c|c|c|c|c|c|c|c|c|c|c|c|c|c|c|}
\hline Sample \# & $\mathrm{pH}$ & Buffered pH & $\begin{array}{c}\text { Total C } \\
(\%)\end{array}$ & $\begin{array}{c}\text { EC } \\
(\text { mmhos/cm) }\end{array}$ & $\begin{array}{c}\text { Total N } \\
(\%)\end{array}$ & $\begin{array}{c}\mathrm{P} \\
(\mathrm{ppm})\end{array}$ & $\begin{array}{c}\mathrm{K} \\
(\mathrm{ppm})\end{array}$ & $\begin{array}{c}\mathrm{Ca} \\
(\mathrm{ppm})\end{array}$ & $\begin{array}{c}\mathrm{Mg} \\
(\mathrm{ppm})\end{array}$ & $\begin{array}{c}\mathrm{Cu} \\
(\mathrm{ppm})\end{array}$ & $\begin{array}{c}\mathrm{Zn} \\
(\mathrm{ppm})\end{array}$ & $\begin{array}{c}\mathrm{Fe} \\
(\mathrm{ppm})\end{array}$ & $\begin{array}{c}\mathrm{Mn} \\
\text { (ppm) }\end{array}$ & $\begin{array}{c}\mathrm{B} \\
(\mathrm{ppm})\end{array}$ \\
\hline 1 & 5.6 & 6.6 & 6.8 & 0.88 & 0.29 & 178 & 240 & 3050 & 160 & 0.6 & 15 & 25 & 45 & 0.5 \\
\hline 2 & 5.4 & 6.5 & 6.6 & 1.28 & 0.32 & 130 & 280 & 3100 & 175 & 0.6 & 12 & 30 & 38 & 0.7 \\
\hline 3 & 5.6 & 6.7 & 6.4 & 0.98 & 0.30 & 162 & 225 & 2600 & 175 & 0.6 & 13 & 30 & 35 & 0.7 \\
\hline 4 & 5.5 & 6.5 & 5.5 & 1.20 & 0.30 & 108 & 200 & 2100 & 155 & 0.6 & 9.3 & 25 & 24 & 0.5 \\
\hline Average & 5.5 & 6.5 & 6.32 & 1.085 & 0.302 & 144.5 & 236.3 & 2713 & 166 & 0.6 & 12.3 & 27.5 & 35.5 & 0.6 \\
\hline
\end{tabular}

${ }^{1}$ Analyses conducted by Pacific Soil Analysis Inc., Richmond, Canada. 
Table 3. Small grain cultivars used for performance evaluation during 2010 spring season.

\begin{tabular}{|c|c|c|c|c|c|}
\hline Type & Cultivar & Type/Characteristics & $\begin{array}{c}100 \text { Seed } \\
\text { Weight (g) }\end{array}$ & $\begin{array}{l}\text { Seed Rate } \\
\left(\mathrm{g} / \mathrm{m}^{2}\right)\end{array}$ & Source \\
\hline \multicolumn{6}{|c|}{ Wheat } \\
\hline \multirow{6}{*}{$\begin{array}{c}\text { Commercial } \\
\text { Cultivars }\end{array}$} & Scarlet & Hard red spring wheat, 6-row, awned & 4.2 & 15 & AAFC ${ }^{1}$, Canada \\
\hline & Lillian & Canada western red spring wheat, 6-row, awnless & 3.7 & 13 & AAFC $^{1}$, Canada \\
\hline & Snowstar & Hard white spring wheat, 6-row, awnless & 2.9 & 10 & $\mathrm{AAFC}^{1}$, Canada \\
\hline & Norwell & Hard red spring wheat, 6-row, awned & 4.0 & 14 & BC, Canada \\
\hline & Strongfield & Canadian Western Amber Durum, 6-row, awned & 4.6 & 16 & BC, Canada \\
\hline & Snowbird & Hard white spring wheat, 6-row, awnless & 3.4 & 12 & BC, Canada \\
\hline \multirow{12}{*}{$\begin{array}{l}\text { Heirloom } \\
\text { Cultivars }\end{array}$} & Red Fife & Hard red spring wheat, 6-row, awnless, mother of all Canadian Wheat & 3.8 & 14 & BC, Canada \\
\hline & Glenn & Hard red spring wheat, 6-row, awned & 2.5 & 9 & Maine, USA \\
\hline & Red Bobs-222 & Hard red spring wheat, 6-row, awnless & 3 & 11 & BC, Canada \\
\hline & Calcutta & Hard red spring wheat, 6-row, awned & 2.8 & 10 & BC, Canada \\
\hline & Cerebs & Hard red spring wheat, 6-row, awned & 3.4 & 12 & BC, Canada \\
\hline & Sounders & Hard red spring wheat, 6-row, awnless & 2.3 & 8.5 & BC, Canada \\
\hline & Emmer-1 & Primitive, 2-row, flat and long spike, hulled, awned & 9.1 & 32 & BC, Canada \\
\hline & Emmer-2 & Primitive, 2-row, flat but short spike, hulled, awned & 6.5 & 23 & BC, Canada \\
\hline & Einkorn & Primitive, 2-row, hulled, flat black spike, awned & 3 & 11 & BC, Canada \\
\hline & Black Bearded & Tall, beautiful large head, 6-row, awned & 4.6 & 16.5 & Minnesota, USA \\
\hline & Reward & Hard red, Canadian heirloom, 6-row, awnless & 4.2 & 15 & Washington, USA \\
\hline & Pacific Blue Stem & White spring, 6-row, awnless & 5.3 & 19 & Oregon, USA \\
\hline \multirow{7}{*}{$\begin{array}{c}\text { Commercial } \\
\text { Cultivars }\end{array}$} & McGwire & 2-row, awned, hulless, malting type & 4.2 & 15 & BC, Canada \\
\hline & Camus & 2 row, awned and hulled & 4.9 & 17 & AAFC $^{1}$, Canada \\
\hline & Oxbridge & 2-row, awned, hulled, UK spring barley & 4.7 & 17 & BC, Canada \\
\hline & Westminster & 2-row, awned, hulled, UK spring barley & 5.4 & 19 & BC, Canada \\
\hline & Decanter & 2-row, awned, hulled, UK spring barley & 4.5 & 16 & BC, Canada \\
\hline & CDC Gainer & 2-row, awned, Canadian hulless, malting type & 4.4 & 16 & BC, Canada \\
\hline & Sunshine & 6-row, awned, early, hulless barley & 3.4 & 12 & Alaska, USA \\
\hline \multirow{9}{*}{$\begin{array}{l}\text { Heirloom } \\
\text { Cultivars }\end{array}$} & Purple (Black) & 6-row, awned, hulless, brown-seeded barley & 4.2 & 15 & BC, Canada \\
\hline & Hooded (Black) & 6-row, awnless, hulless, brown-seeded barley & 3.3 & 12 & BC, Canada \\
\hline & Jet (Black) & 2-row, awned, hulless, black-seeded barley & 3.7 & 13 & Idaho, USA \\
\hline & Dolma & 6-row, awned, hulless, easy threshing & 3.3 & 12 & Idaho, USA \\
\hline & Andie & 6-row, awnless, hulless & 3.2 & 12 & California, USA \\
\hline & Ethiopian Hulless & 2-row, awned, hulless, heat resistant & 4.2 & 15 & California, USA \\
\hline & Excelsior (Black) & 6-row, awned, hulless, brown-seeded barley & 4.3 & 15 & BC, Canada \\
\hline & Himalayan & 6-row, awned, hulless & 3.9 & 14 & BC, Canada \\
\hline & Burbank (Brown) & 6-row, awned, hulless, easy threshing & 2.4 & 9 & Maine, USA \\
\hline
\end{tabular}

${ }^{1}$ Agriculture and Agri-Food Canada.

moisture. Protein aassessment was conducted in the Faculty of Food, Nutrition and Health Lab at UBC in February 2011.
Crop management parameters: General observations were made 30 and 70 days after sowing (DAS) on the type and number of weeds present and insect pest and 
Table 4. Legume crops and cultivars used for evaluation during 2010 spring season.

\begin{tabular}{|c|c|c|c|c|}
\hline SN & Name of Cultivar & Cultivar Characteristics & $\begin{array}{l}\text { Sowing Density } \\
\left(\mathrm{seed} / \mathrm{m}^{2}\right)\end{array}$ & Sourcing Area \\
\hline \multicolumn{5}{|c|}{ Pea } \\
\hline 1 & Reward & Powdery mildew resistance field pea & $66\left(30 \times 5 \mathrm{~cm}^{2}\right)$ & $\mathrm{AAFC}^{1}$, Canada \\
\hline 2. & Snowbird & Very early, dwarf plants, entire pods are edible & $66\left(30 \times 5 \mathrm{~cm}^{2}\right)$ & Wisconsin, USA \\
\hline 3. & Corgi & Small round dark green pod, very sweet and prolific & $66\left(30 \times 5 \mathrm{~cm}^{2}\right)$ & California, USA \\
\hline 4. & Golden & Edible yellow pods, purple flowers, good bearer & $66\left(30 \times 5 \mathrm{~cm}^{2}\right)$ & Maine, USA \\
\hline 5. & De Grace & Early, no disease, compact, better than modern sugar & $66\left(30 \times 5 \mathrm{~cm}^{2}\right)$ & Connecticut, USA \\
\hline \multicolumn{5}{|c|}{ Favabean } \\
\hline 1. & Crimson Flowered & Short red edible flower, excellent in salads, smaller bushes, bright green seeds & $33\left(30 \times 10 \mathrm{~cm}^{2}\right)$ & Washington, USA \\
\hline 2. & Bergeron & Early maturity, one-picking, dwarf plant and short pod & $33\left(30 \times 10 \mathrm{~cm}^{2}\right)$ & Vermont, USA \\
\hline 3. & Windsor & Bush type, classic heir-loom variety of flat bean & $33\left(30 \times 10 \mathrm{~cm}^{2}\right)$ & Maine, USA \\
\hline 4. & Bell & Short pod, small and roundish seed & $33\left(30 \times 10 \mathrm{~cm}^{2}\right)$ & BC, Canada \\
\hline 5. & Andy & Longer growing season, tall plant and longest pod & $33\left(30 \times 10 \mathrm{~cm}^{2}\right)$ & BC, Canada \\
\hline \multicolumn{5}{|c|}{ Broadbean/Kidneybean } \\
\hline 1. & Artec Red Kidney & Dry kidney bean, bush-type, dark amber seed & $33\left(30 \times 10 \mathrm{~cm}^{2}\right)$ & BC, Canada \\
\hline 2. & Red Kidney & Dry kidney bean, bush-type, red seed & $33\left(30 \times 10 \mathrm{~cm}^{2}\right)$ & BC, Canada \\
\hline 3. & Black Turtle & Dry bush bean, small and black seed & $33\left(30 \times 10 \mathrm{~cm}^{2}\right)$ & BC, Canada \\
\hline 4. & Candy & Dry kidney bean, vine-type, colored seed with red spots & $33\left(30 \times 10 \mathrm{~cm}^{2}\right)$ & BC, Canada \\
\hline 5. & Golden Rocky & Dry bush bean, black seeded with white eye & $33\left(30 \times 10 \mathrm{~cm}^{2}\right)$ & BC, Canada \\
\hline \multicolumn{5}{|c|}{ Soyabean } \\
\hline 1. & Black Jet & Tall plant, black seed, grain type & $33\left(30 \times 10 \mathrm{~cm}^{2}\right)$ & BC, Canada \\
\hline 2. & Edamme & Dwarf plant, yellow seed, vegetable type & $33\left(30 \times 10 \mathrm{~cm}^{2}\right)$ & BC, Canada \\
\hline \multicolumn{5}{|c|}{ Lentil } \\
\hline 1 & Crimson & Brown lentils with red cotyledons & $200\left(20 \times 2.5 \mathrm{~cm}^{2}\right)$ & $\mathrm{AAFC}^{1}$, Canada \\
\hline 2 & Essex & Green lentil with yellow cotyledons & $200\left(20 \times 2.5 \mathrm{~cm}^{2}\right)$ & $\mathrm{ARS}^{2}$, Pullman, USA \\
\hline
\end{tabular}

${ }^{1}$ Agriculture and Agri-Food Canada; ${ }^{2}$ Agricultural Research Service/USDA.

disease pressures with regard to type and nature of damage. Cereal stem, leaf and head diseases of economic importance including Fusarium (Fusarium spp.), Barley Stripe (Helminthosporium gramineum), Scald or Leaf Blotch (Rhynchosporium secalis), Stem/Leaf/Stripe/Yellow/ Brown Rust (Puccinia spp.), Septoria Leaf Spot or Glume Blotch (Septoria tritici) were monitored and noted over the course of the season. Plants were inspected for diseases and leaf resistance during flowering to milking stage, Zadoks growth stages (ZGS) as devised by Zadoks et al. [19] and expanded by Tottman [20]. Disease assessments were conducted on five random plants from each plot. Rating was done according to the assessment key (Table 5, Figure 1) used by the Ecofriendly Crop Rotation Project operated in Delta, BC by the Delta Farmers' Institute \& Faculty of Land and Food Systems, UBC, Canada [21].

Lodging was assessed before harvest on a 0 - 10 scale (i.e., 0 for $100 \%$ erect plants, and 10 for complete lodging of whole plot) based on visual observation. The angle
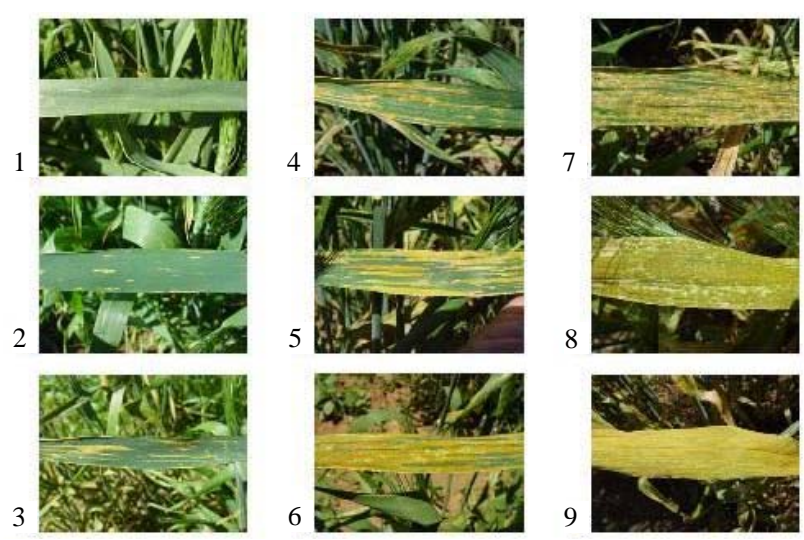

Figure 1. Disease assessment score and severity of leaf damage.

of lodging was also assessed. Plants that were completely bent down to the ground $\left(60^{\circ}\right.$ to $\left.90^{\circ}\right)$ with all spikes touching the soil surface were considered completely lodged while the plants up to $60^{\circ}$ without having spikes 
Table 5. Disease assessment key adopted during 2010 spring trial at UBC farm (after Temple, 2009).

\begin{tabular}{|c|c|}
\hline Score & Description \\
\hline 1 & Highly resistant: no visible symptoms \\
\hline 2 & $\begin{array}{l}\text { Highly resistant: occasional symptoms of infection including } \\
\text { necrotic flecks and small stripes without sporulation }\end{array}$ \\
\hline 3 & $\begin{array}{l}\text { Resistant: symptoms evident and may include stripes with } \\
\text { necrosis and chlorosis, limited sporulation, and affected leaf } \\
\text { area up to } 15 \%\end{array}$ \\
\hline 4 & $\begin{array}{l}\text { Moderately resistant: sporulating areas arranged in stripes, some } \\
\text { chlorosis and necrosis, and affected leaf area up to } 30 \%\end{array}$ \\
\hline 5 & $\begin{array}{l}\text { Intermediate: Sporulating areas arranged in stripes with some } \\
\text { chlorosis, and affected leaf area up to } 50 \%\end{array}$ \\
\hline 6 & $\begin{array}{l}\text { Moderately susceptible: sporulating stripes and affected leaf } \\
\text { area up to } 70 \%\end{array}$ \\
\hline 7 & $\begin{array}{l}\text { Moderately susceptible to susceptible: sporulating stripes } \\
\text { merging into broader leaf areas supporting symptoms, chlorosis } \\
\text { and necrosis evident, leaf area affected up to } 90 \%\end{array}$ \\
\hline 8 & $\begin{array}{l}\text { Susceptible: sporulation across the whole leaf surface with no } \\
\text { stripes but with evidence of chlorotic areas }\end{array}$ \\
\hline 9 & $\begin{array}{l}\text { Highly susceptible: abundant sporulation across the whole leaf } \\
\text { area with no evidence of stripes }\end{array}$ \\
\hline 10 & Dead leaf \\
\hline
\end{tabular}

contacting the soil surface were considered partially lodged. The scores were averaged and transformed into percentages.

Legume nodulation: Nodulation was assessed by examining the roots of 3 randomly selected plants, 30 and 70 DAS, from each plot. Measurements included earliness of nodulation, total nodule number, color and distribution followed by the visual nodulation scores as described in Table 6. Visual scoring used a 0 to 5 scale and was based on nodule number, size, pigmentation and distribution [22]. The scores from all plants were added and then divided by the number of plants to obtain a mean nodule score.

Data were compiled and subjected to analysis using Microsoft Excel and MSTATC software. Simple correlations were run between selected parameters using Statistical Package for Social Science (SPSS) software wherever necessary.

\section{Results and Discussion}

\subsection{Plant-Based Parameters}

Wheat: The response of commercial and heirloom wheat cultivars on key vegetative and reproductive parameters is shown (Table 7). In general, heirloom cultivars showed notable response in a number of parameters compared with commercial cultivars including later maturity, taller plants, greater number of spikes per $\mathrm{m}^{2}$, longest spike, higher number of seed per spike, and greater seed weight to volume ratio. There existed significant variation among the heirloom cultivars while the commercial cultivars were more uniform for a number of plant based parameters. Significant variation was also observed between 6-row hulless and 2-row hulled cultivars with 2-row hulled-type showing higher disease resistance but with lower grain yield and HI. Commercial cultivars displayed the highest 1000 seed weights, grain weights and HIs (Table 7).

Heirloom cultivars matured 1 - 4 weeks later as compared to the commercial cultivars, though harvest date varied. "Pacific Blue Stem" took 135 days to harvest followed by "Einkorn" and "Red Fife" (125 days) while "Sounders" and "Reward" matured the earliest (95 days). Except for "Snowbird" and "Snowstar", commercial cultivars were near the average of 105 days to harvest. "Snowstar" and "Snowbird" matured 5 - 15 days earlier than the other commercial cultivars.

Heirloom cultivars produced taller plants compared to

Table 6. Rating key for nodule assessment (after Corbin et al., 1977).

\begin{tabular}{|c|c|c|c|}
\hline & Field Assessment Key & & Mean Score and Indication \\
\hline Score & Visual Observation & Mean Nodule Score & Indication \\
\hline 1 & $\begin{array}{l}<5 \text { in the crown-root zone (regarded as the region up to } 5 \mathrm{~cm} \text { below } \\
\text { the first lateral roots) with no nodules on elsewhere on the root system }\end{array}$ & 0 - 1 & $\begin{array}{l}\text { Very poor nodulation and probably little or no } \mathrm{N}_{2} \\
\text { fixation }\end{array}$ \\
\hline 3 & $\begin{array}{l}>10 \text { in the crown-root zone with }<5 \text { nodules on elsewhere on the root } \\
\text { system }\end{array}$ & $2-3$ & $\begin{array}{l}\text { Fair nodulation; } \mathrm{N}_{2} \text { fixation may not be sufficient } \\
\text { to supply the } \mathrm{N} \text { demand of the crop }\end{array}$ \\
\hline 4 & $\begin{array}{l}>10 \text { in the crown-root zone with } 5 \text { - } 10 \text { nodules on elsewhere on the } \\
\text { root system }\end{array}$ & $3-4$ & Good nodulation; good potential for $\mathrm{N}_{2}$ fixation \\
\hline
\end{tabular}


Table 7. Response of commercial wheat cultivars to organic production systems during 2010 spring season at UBC farm.

\begin{tabular}{|c|c|c|c|c|c|c|c|c|c|c|c|}
\hline Type & Cultivar & Days to Harvest & $\begin{array}{l}\text { Harvest } \\
\text { Height }(\mathrm{cm})\end{array}$ & $\begin{array}{c}\text { No. of } \\
\text { Spike/m² }\end{array}$ & $\begin{array}{c}\text { Spike } \\
\text { Length }(\mathrm{cm})\end{array}$ & $\begin{array}{c}\text { Seeds } \\
\text { per Spike }\end{array}$ & $\begin{array}{c}\text { Test } \\
\text { Weight }^{1}(\mathrm{~g})\end{array}$ & $\begin{array}{c}\text { Grain } \\
\text { Yield }\left(\mathrm{g} / \mathrm{m}^{2}\right)\end{array}$ & $\begin{array}{c}\text { Grain } \\
\text { Yield }^{2}(\mathrm{t} / \mathrm{h})\end{array}$ & $\begin{array}{l}\mathrm{HI}^{3} \\
(\%)\end{array}$ & $\mathrm{W}: \mathrm{V}^{4}$ \\
\hline \multirow{6}{*}{$\begin{array}{l}\text { Commercial } \\
\text { Cultivars }\end{array}$} & Lillian & $105(100-105)$ & 104 & 461 & 7.5 & 33.3 & 41.7 & 440 & 4.4 & 45.9 & 0.82 \\
\hline & Scarlet & $105(105-110)$ & 103 & 500 & 9.2 & 38.7 & 48.0 & 544 & 5.4 & 48.4 & 0.83 \\
\hline & Norwell & $105(105-110)$ & 114 & 588 & 8.2 & 42.0 & 44.7 & 525 & 5.3 & 42.7 & 0.84 \\
\hline & Snowstar & $100(95-100)$ & 103 & 726 & 6.9 & 34.0 & 32.7 & 472 & 4.7 & 45.5 & 0.81 \\
\hline & Strongfield & $110(105-110)$ & 98 & 426 & 6.0 & 36.7 & 42.7 & 500 & 5.0 & 46.1 & 0.83 \\
\hline & Snowbird & $100(95-100)$ & 122 & 655 & 6.2 & 34.0 & 39.5 & 477 & 4.8 & 43.2 & 0.82 \\
\hline \multirow{15}{*}{$\begin{array}{l}\text { Heirloom } \\
\text { Cultivars }\end{array}$} & Red Fife & $125(120-125)$ & 135 & 419 & 10.6 & 38.7 & 43.7 & 407 & 4.1 & 37.4 & 0.81 \\
\hline & Glenn & $110(105-110)$ & 109 & 602 & 7.3 & 38.3 & 40.0 & 505 & 5.1 & 42.4 & 0.85 \\
\hline & Red Wheat & $100(100-105)$ & 109 & 574 & 6.7 & 27.3 & 40.5 & 361 & 3.6 & 30.5 & 0.82 \\
\hline & Red Bobs & $105(100-105)$ & 133 & 704 & 9.1 & 50.0 & 37.7 & 462 & 4.6 & 32.5 & 0.80 \\
\hline & Calcutta & $105(105-110)$ & 114 & 722 & 9.3 & 31.7 & 34.4 & 420 & 4.2 & 31.9 & 0.80 \\
\hline & Cerebs & $105(105-110)$ & 122 & 588 & 8.5 & 29.3 & 34.7 & 488 & 4.9 & 41.9 & 0.78 \\
\hline & Sounders & $95(95-100)$ & 100 & 712 & 7.3 & 31.3 & 38.5 & 458 & 4.6 & 36.5 & 0.83 \\
\hline & Emmer-1 & $110(110-115)$ & 105 & 722 & 5.5 & 29.0 & 40.6 & 377 & 3.8 & 37.7 & 0.65 \\
\hline & Emmer-2 & $105(105-110)$ & 108 & 628 & 5.6 & 21.3 & 42.4 & 389 & 3.9 & 43.7 & 0.67 \\
\hline & Einkorn & $125(120-125)$ & 126 & 544 & 7.2 & 36.3 & 26.6 & 281 & 2.8 & 36.1 & 0.49 \\
\hline & Black Bearded & $105(105-110)$ & 116 & 702 & 6.8 & 41.0 & 39.3 & 448 & 4.5 & 31.0 & 0.75 \\
\hline & Reward & $95(95-100)$ & 127 & 826 & 7.2 & 27.7 & 41.0 & 520 & 5.2 & 32.5 & 0.85 \\
\hline & Pacific Blue Stem & $135(135-140)$ & 118 & 668 & 9.3 & 24.0 & 32.0 & 252 & 2.5 & 21.2 & 0.74 \\
\hline & $\mathrm{SE}( \pm)$ & 3.67 & 5.23 & 14.5 & 1.02 & 3.99 & 2.82 & 32 & 0.31 & 2.66 & 0.04 \\
\hline & $\mathrm{LSD}_{0.05}$ & 7.35 & 10.45 & 29 & 2.05 & 8 & 5.65 & 65 & 0.65 & 5.32 & 0.08 \\
\hline
\end{tabular}

${ }^{1} 1000$ seed weight; ${ }^{2}$ Calculated at $12.5 \%$ moisture; ${ }^{3}$ Harvest Index; ${ }^{4}$ Seed weight to volume ratio.

commercial cultivars. The tallest cultivar was "Red Fife” $(135 \mathrm{~cm})$ followed by “Red Bobs” (133 cm), and “Reward” (127). Commercial cultivars produced short to medium plants, the shortest being the "Strongfield" (98 $\mathrm{cm})$ accompanied by the heirloom "Sounders" $(100 \mathrm{~cm})$. A positive but very weak relationship $\left(r^{2}=0.21\right)$ was observed between harvest dates and plant height. The earliest heirloom cultivar "Reward" produced taller plants $(127 \mathrm{~cm})$ while the latest commercial cultivar "Strongfield" produced the shortest $(98 \mathrm{~cm})$ plant.

Except for "Red Fife", heirloom cultivars produced greater numbers of spikes per unit area compared to commercial cultivars (Table 7) and were mainly due to difference in seeding density. The lowest spike density $\left(419 / \mathrm{m}^{2}\right)$ in "Red Fife" was due to less seeding density (350 in production trials compared to 450 seeds per $\mathrm{m}^{2}$ in seed plots for other heirloom cultivars) and low germination rate (as low as 20\%). However, the spike density of 419 was achieved as it produced greater number of tillers per plant. The commercial cultivar "Lillian" showed similar responses.

"Red Fife", a 6-row hulless heirloom cultivar, produced the longest spikes $(10.6 \mathrm{~cm})$ followed by "Cal- cutta” and "Pacific Blue Stem” $(9.3 \mathrm{~cm})$ while "Red Bobs” gave the highest number of seed per spike. However, 2-row heirloom hulled wheats (e.g., Emmer and Enkorn series) produced the shortest spikes with the fewest number of seeds per spike resulting in comparatively lower grain yields than 6-row hulless cultivars (Table 7).

The 6-row heirloom hulless cultivars (e.g., "Reward", "Glenn”, “Cerebs”, "Red Bobs”, and "Sounders”) produced grain yields (5.2, 5.1, 4.9, 4.6 and $4.6 \mathrm{t} / \mathrm{h}$, respectively) comparable to the commercial cultivars. Despite having a moderate number of seed per spike (39) and comparatively higher 1000 seed weight (44 gm), "Red Fife" produced lower yield $(4.1 \mathrm{t} / \mathrm{h})$ and could be associated with fewer spikes per unit area. The heirloom cultivars typically had lower HI as they produced taller plants (i.e., greatest biomass). The cultivar "Pacific Blue Stem" had the lowest yield (2.5 t/h) and HI (21\%) which may be due to the spikes containing unfilled spikelets with mold developing, perhaps due to the later harvest.

Among commercial cultivars, "Scarlet", a 6-row hulless, gave the longest spikes $(9.2 \mathrm{~cm})$ with a moderate number of seeds per spike (39), the highest 1000 seed weight (48 g) resulting in highest grain yields $(5.4 \mathrm{t} / \mathrm{h})$ and $\mathrm{HI}$ 
(48.4\%). It was followed by "Norwell” with the highest number of seeds per spike (42), good 1000 seed weight (45 g), and grain yield (5.3 t/h).

Heirloom wheat showed greater weight to volume ratio compared to commercial cultivars with "Glenn” and "Reward" displaying the greatest weight to volume ratio (0.85:1). The ratio was lowest in 2-row hulled wheat (e.g., Emmer and Enkorn series) as the hulled (with awn) and longer grains occupied more volume but lighter in weight. The ratio was highest in the hulless cultivars with smaller sized and more uniform seeds.

Overall, the yield from commercial cultivars was greater than the Canadian yield average $(\sim 3 \mathrm{t} / \mathrm{h})$. This finding is in line with the reports of [23] who reported the yield of two different cultivars "Reaper" and "Monopol” as $5.8 \mathrm{t} / \mathrm{h}$ and $7.2 \mathrm{t} / \mathrm{h}$, respectively, when grown at the UBC Farm. Similar yield responses were reported by Kidwell et al. [24] in eastern Washington using other cultivars. They found the grain yield averages of "Kelse", "WestBred 926”, “Tara 2002”, and "Hank” as 5.2, 5.3, 5.4 and 5.7 $\mathrm{t} / \mathrm{h}$, respectively. In addition, Temple [21] also reported a yield of $5.5 \mathrm{t} / \mathrm{h}$ from "Norwell" when working with spring wheat grown by farmer-cooperators in Delta, BC.

Barley: Production characteristics of the commercial and heirloom barley cultivars are presented (Table 8).
Overall, heirloom and commercial cultivars did not differ materially with respect to a number of plant based parameters including plant height, spike length, and seed weight to volume ratio. However, a number of heirloom cultivars displayed greater responses including earliness, number of spikes per $\mathrm{m}^{2}$, grain yield and seed weight to volume ratio (Table 8).

A clear difference was observed in maturity times between hulless (e.g., "Purple”, "Sunshine”, "Dolma”, “Andie”, "Excelsior”, "Himalayan”, “Jet”, “Ethiopian” and "CDC Gainer”) and hulled (e.g., "Oxbridge”, "Westminster”, "Decanter”, “Copeland” and "Camus”) cultivars with the hulless-types maturing 1 - 2 weeks earlier than the hulled-types. This was true for both the 2 and 6-row hulless cultivars with 2-row hulless (e.g., "Jet”, "Ethiopian" and "CDC Gainer") and 6-row hulless (e.g., "Purple”, "Sunshine”, "Dolma”, “Andie”, “Excelsior” and "Himalayan") maturing 1 - 2 weeks earlier than 2-row hulled-types (e.g., “Oxbridge”, "Westminster”, “Decanter”, "Copeland" and "Camus”). One exception was the 6-row hulless cultivar "Hooded" that required 100 days to mature.

Except for "CDC Gainer" and "Copeland”, 2-row cultivars produced the shortest plants $(65-80 \mathrm{~cm})$ compared with 6-row cultivars. UK hulled barley “Oxbridge” pro-

Table 8. Performance of commercial and heirloom barley cultivars to organic production during 2010 spring season at UBC farm.

\begin{tabular}{|c|c|c|c|c|c|c|c|c|c|c|c|}
\hline Туре & Cultivar & Days to Harvest & $\begin{array}{c}\text { Harvest } \\
\text { Height }(\mathrm{cm})\end{array}$ & $\begin{array}{c}\text { No. of } \\
\text { Spike/m² }\end{array}$ & $\begin{array}{c}\text { Spike } \\
\text { Length }(\mathrm{cm})\end{array}$ & $\begin{array}{c}\text { Seeds } \\
\text { per Spike }\end{array}$ & $\begin{array}{c}\text { Test } \\
\text { Weight }^{1}(\mathrm{~g})\end{array}$ & $\begin{array}{c}\text { Grain } \\
\text { Yield }\left(\mathrm{g} / \mathrm{m}^{2}\right)\end{array}$ & $\begin{array}{c}\text { Grain } \\
\text { Yield (t/h) }\end{array}$ & $\begin{array}{l}\mathrm{HI}^{3} \\
(\%)\end{array}$ & $\mathrm{W}: \mathrm{V}^{4}$ \\
\hline \multirow{8}{*}{$\begin{array}{l}\text { Commercial } \\
\text { Cultivars }\end{array}$} & Copeland & $95(90-95)$ & 100 & 565 & 7.6 & 27.7 & 53.0 & 510 & 5.1 & 45.5 & 0.66 \\
\hline & McGwire & $90(90-95)$ & 73 & 594 & 9.0 & 27.0 & 40.1 & 520 & 5.2 & 46.9 & 0.83 \\
\hline & Camus & $95(90-95)$ & 81 & 510 & 7.8 & 26.7 & 54.0 & 498 & 5.0 & 53.8 & 0.68 \\
\hline & Oxbridge & $95(90-95)$ & 65 & 766 & 7.9 & 21.3 & 55.3 & 580 & 5.8 & 53.8 & 0.66 \\
\hline & Westminster & $100(100-105)$ & 80 & 804 & 7.8 & 23.3 & 57.7 & 570 & 5.7 & 52.9 & 0.71 \\
\hline & Decanter & $100(100-105)$ & 71 & 804 & 8.2 & 26.0 & 57.9 & 560 & 5.6 & 57.8 & 0.68 \\
\hline & CDC Gainer & $90(90-95)$ & 100 & 880 & 8.5 & 22.0 & 38.5 & 507 & 5.1 & 39.0 & 0.79 \\
\hline & Sunshine & $85(80-85)$ & 92 & 668 & 6.4 & 50.0 & 31.1 & 496 & 4.9 & 42.0 & 0.79 \\
\hline \multirow{11}{*}{$\begin{array}{l}\text { Heirloom } \\
\text { Cultivars }\end{array}$} & Purple (Black) & $85(80-85)$ & 87 & 496 & 6.0 & 38.0 & 46.9 & 388 & 3.9 & 45.2 & 0.86 \\
\hline & Hooded (Black) & $100(100-105)$ & 92 & 358 & 7.6 & 46.0 & 38.3 & 423 & 4.2 & 48.3 & 0.79 \\
\hline & Jet (Black) & $80(80-85)$ & 75 & 736 & 6.9 & 15.7 & 48.5 & 552 & 5.5 & 29.2 & 0.73 \\
\hline & Dolma & $80(75-80)$ & 78 & 656 & 5.9 & 34.3 & 36.3 & 488 & 4.9 & 41.7 & 0.78 \\
\hline & Andie & $80(75-80)$ & 92 & 658 & 5.5 & 36.0 & 34.3 & 420 & 4.2 & 37.7 & 0.81 \\
\hline & Ethiopian Hulless & $85(80-85)$ & 85 & 576 & 7.1 & 15.7 & 49.8 & 444 & 4.4 & 34.4 & 0.77 \\
\hline & Excelsior (Black) & $90(90-95)$ & 82 & 532 & 5.4 & 33.0 & 42.9 & 297 & 2.9 & 43.1 & 0.83 \\
\hline & Himalayan & $80(80-85)$ & 89 & 648 & 6.5 & 36.7 & 39.3 & 420 & 4.2 & 41.8 & 0.77 \\
\hline & Burbank & $95(90-95)$ & 102 & 500 & 5.8 & 52.0 & 38.7 & 450 & 4.5 & 32.1 & 0.81 \\
\hline & $\mathrm{SE}( \pm)$ & 3.49 & 4.18 & 12.5 & 0.85 & 3.45 & 3.22 & 32 & 0.29 & 3.12 & 0.05 \\
\hline & $\mathrm{LSD}_{0.05}$ & 7.0 & 8.36 & 25 & 1.7 & 6.9 & 6.45 & 65 & 0.6 & 6.25 & 0.1 \\
\hline
\end{tabular}

${ }^{1} 1000$ seed weight; ${ }^{2}$ Calculated at $12.5 \%$ moisture; ${ }^{3}$ Harvest Index; ${ }^{4}$ Seed weight to volume ratio. 
duced the shortest plants $(65 \mathrm{~cm})$ while the Canadian hulless "CDC Gainer" and hulled "Copeland" produced the tallest plants $(100 \mathrm{~cm})$. UK spring barleys (e.g., "Oxbridge", "Westminster" and "Decanter") produced greater number of spikes per unit area compared to other commercial cultivars which was mainly due to differences in seeding density. The fewer spikes in "Hooded" $\left(358 / \mathrm{m}^{2}\right)$, a 6-row hulless barley, was due to poor germination (30\%).

The 6-row hulless cultivars (e.g., "Burbank", "Sunshine”, "Hooded”, "Purple”, "Dolma”, “Andie”, "Excelsior" and "Himalayan") produced greater numbers of seeds per spike and seed weight to volume ratios but typically consisted of shorter spikes, lower 1000 seed weight, grain yield and $\mathrm{HI}$ than 2-row cultivars. On the other hand, the 2-row hulled cultivars (e.g., "Oxbridge", "Westminster", "Decanter", "Copeland" and "Camus"), displayed greater 1000 seed weight, yield and HI but consisted of lower weight to volume ratios than the 2-row hulless cultivars (e.g., "Jet”, "Ethiopian” and “CDC Gainer").

The 2-row UK spring barley "Oxbridge" had the highest yield $(5.8 \mathrm{t} / \mathrm{h})$ followed by "Westminster" (5.7 t/h) and "Decanter" ( $5.6 \mathrm{t} / \mathrm{h})$ while the other commercial barleys yielded slightly more than $5 \mathrm{t} / \mathrm{h}$ (Table 8). Hulless barleys had the greatest weight to volume ratio (up to 0.86:1) with 6-rowed cultivars showing slightly higher ratios than 2-row hulless cultivars. Black barleys also appeared promising with 2-row "Jet" producing the highest yield ( $5.5 \mathrm{t} / \mathrm{h})$ followed by 6-row hulless "Hooded" (4.2 t/h). The cultivars "Sunshine" and "Dolma", 6-row brown barleys, also produced greater yields ( $4.9 \mathrm{t} / \mathrm{h})$ compared to other hulless barleys.

Legumes: Production traits of the different legume crops and cultivars are shown (Table 9). The heirloom peas "Corgi", "De Grace", "Snowbird", and "Golden" were early maturing (75 - 80 DAS) with greater shell to seed ratio (up to 1:6.4) but produced relatively lower yields, 1000 seed weights, and seed weight to volume ratios compared to the commercial pea cultivar "Reward". "Reward" produced higher yields although there was significant variation between the sampled plants and the remaining plot ( $3 \mathrm{t} / \mathrm{h}$ vs. $1.2 \mathrm{t} / \mathrm{h}$, respectively) due to poor germination affecting plant density. Neither lentil cultivar produced satisfactory results in terms of yield though they had excellent vegetative growth and flowered. However, most of the pods were barren and/or underdeveloped, perhaps due to low temperature. The cultivar "Essex" produced relatively good pods containing white seeds whereas "Crimson" had more pods per plant but containing no or only undersized brown seeds.

Among favabean cultivars (Table 9), heirloom cultivar "Bergeron" matured earliest (95 - 100 DAS) producing the shortest plants $(63.8 \mathrm{~cm})$, while "Crimson Flowered" matured latest (120 - 125 DAS). Except for "Bergeron", all other cultivars required at least two harvests at 10 day intervals, with "Andy" and "Windsor" requiring three. The cultivar "Bell" developed an upright growth habit and produced the highest number of pods per plant (7.6) containing relatively small round seeds that gave the highest seed weight to volume ratio (0.81:1) and yield $(2.9$ t/h). Cultivars "Andy", "Windsor" and "Crimson Flowered" produced longer pods than "Bell" (23, 14.6 and $10.3 \mathrm{~cm}$, respectively) containing flat large-sized seeds. As a result, 1000 seed weight was highest in "Windsor" (1512.8 gm) followed by “Andy" (1383.6 gm).

Kidney beans, although requiring a relatively long growing season (approximately 120 days), did well under UBC's climate (Table 9). On an average, cultivars produced $\sim 3 \mathrm{t} / \mathrm{h}$. Cultivar "Candy”, a vine-type kidney bean, had the longest plants $(97.2 \mathrm{~cm})$ followed by "Black Turtle" $(89.4 \mathrm{~cm})$. On cultivar "Candy", pods rotted before maturity because they were not trellised and received a significant amount of rain while ripening. However, "Black Turtle" pods did not rot, perhaps due to their shorter more round pods that were held above the soil surface. Cultivar "Golden Rocky", a dwarf bush bean cultivar, matured 20 days earlier than other cultivars producing a relatively good yield $(3.2 \mathrm{t} / \mathrm{h})$ and the greatest seed weight to volume ratio (0.88:1).

Soyabean cultivars "Black Jet" and "Edamme" were the latest to mature (130 - 135 DAS) compared with other legumes (Table 9). Plant density was low in "Edamme" $\left(20 / \mathrm{m}^{2}\right)$ due to poor germination but displayed dwarf bushy growth habit. Cultivar "Black Jet" produced the tallest plants $(79.8 \mathrm{~cm})$ with fewer pods per plant (24 vs. 27 in "Edamme") and shorter pods (5 vs. 6 $\mathrm{cm}$ in "Edamme"). However, "Black Jet" had higher yield (3.4 t/h compared to $2 \mathrm{t} / \mathrm{h}$ in Edamme) but most likely due to greater plant density. Cultivar "Edamme" produced large-sized yellow seeds that resulted in greater 1000 seed weight (380.7 gm) compared to "Black Jet" (273.8 gm).

\subsection{Management-Based Parameters}

Weed pressure: The most common weeds were Common Chickweed (Stellaria media), Green Smartweed (Polygonum lapathifolium), Prostrate Knotweed (Polygonum aviculare), Pigweed (Amaranthus spp.), Crab Grass (Digitaria ischaemum), Barnyard Grass (Echinochloa crusgalli), Black nightshade (Solanum nigrum), and Field horsetail (Equisetum arvense). Common Chickweed (Stellaria media), an excellent colonizer that forms succulent mat on the soil surface, covered the whole field starting 20 DAS. Pigweed was observed early in the season in wheat and barley plots along with the chickweed. 
Table 9. Performance of legume cultivars to the organic production during 2010 spring season at the UBC farm.

\begin{tabular}{|c|c|c|c|c|c|c|c|c|c|c|c|c|}
\hline SN & Cultivar & $\begin{array}{c}\text { Days to Seed } \\
\text { Harvest }\end{array}$ & $\begin{array}{c}\text { Harvest } \\
\text { Height }(\mathrm{cm})\end{array}$ & $\begin{array}{c}\text { No. of } \\
\text { Plant } / \mathrm{m}^{2}\end{array}$ & $\begin{array}{l}\text { No. of Pod } \\
\text { per Plant }\end{array}$ & $\begin{array}{l}\text { Pod } \\
\text { Length }(\mathrm{cm})\end{array}$ & $\begin{array}{l}\text { No. of Seed } \\
\text { per Pod }\end{array}$ & $\begin{array}{l}\text { Seed Yield } \\
\text { (g/plot) }\end{array}$ & $\begin{array}{l}\text { Grain } \\
\text { Yield }^{2}(\mathrm{t} / \mathrm{h})\end{array}$ & $\begin{array}{c}\text { Test } \\
\text { Weight }^{1} \text { (g) }\end{array}$ & $\begin{array}{c}\text { Seed to } \\
\text { Shell Ratio }\end{array}$ & $\mathrm{W}: \mathrm{V}^{3}$ \\
\hline \multicolumn{13}{|c|}{ Pea } \\
\hline 1 & Reward* & $90(85-90)$ & 94.6 & 46 & 3.8 & 5.6 & 5.3 & 298.2 & 3.0 & 206.5 & 3.7 & 0.88 \\
\hline 2 & Snowbird & $80(75-80)$ & - & - & - & - & - & 103.6 & 1.0 & 143.0 & 5.2 & 0.81 \\
\hline 3 & Corgi & $80(75-80)$ & - & - & - & - & - & 91.5 & 0.9 & 168.2 & 4.6 & 0.73 \\
\hline 4 & Golden & $80(80-85)$ & - & - & - & - & - & 165.5 & 1.7 & 176.6 & 6.4 & 0.79 \\
\hline 5 & De Grace & $80(75-80)$ & - & - & - & - & - & 89.4 & 0.9 & 128.4 & 3.7 & 0.80 \\
\hline & $\mathrm{SE}( \pm)$ & 3.59 & - & - & - & - & - & 14.3 & 0.14 & 8.54 & 0.21 & 0.06 \\
\hline & $\mathrm{LSD}_{0.05}$ & 7.2 & - & - & - & - & - & 28.6 & 0.29 & 17.09 & 0.42 & 0.13 \\
\hline \multicolumn{13}{|c|}{ Favabean } \\
\hline 1 & Crimson Flowered & $125(120-125)$ & 106.2 & 32 & 5.6 & 10.3 & 3.2 & 264.9 & 2.6 & 1090 & 2.6 & 0.65 \\
\hline 2 & Bergeron & $95(95-100)$ & 63.8 & 28 & 4.0 & 7.0 & 3.2 & 250.6 & 2.5 & 718.1 & 2.3 & 0.74 \\
\hline 3 & Windsor & $115(110-120)$ & 100.0 & 24 & 7.6 & 14.6 & 4.2 & 171.3 & 1.7 & 1512.8 & 2.4 & 0.61 \\
\hline 4 & Bell & $110(110-120)$ & 100.2 & 32 & 7.6 & 7.7 & 3.8 & 291.8 & 2.9 & 533.4 & 2.6 & 0.81 \\
\hline 5 & Andy & $115(110-120)$ & 122.6 & 28 & 6.8 & 23.0 & 5.6 & 278.7 & 2.8 & 1383.6 & 1.8 & 0.69 \\
\hline & $\mathrm{SE}( \pm)$ & 4.25 & 7.36 & 1.5 & 1.25 & 1.31 & 0.72 & 18.65 & 0.19 & 15.75 & 0.25 & 0.06 \\
\hline & $\mathrm{LSD}_{0.05}$ & 8.5 & 14.72 & 3.0 & 2.5 & 2.62 & 1.45 & 37.3 & 0.38 & 31.5 & 0.5 & 0.12 \\
\hline \multicolumn{13}{|c|}{ Broadbean/Kidneybean } \\
\hline 1 & Artec Red Kidney & $120(120-125)$ & 57.6 & 32 & 8.0 & 16.2 & 4.8 & 325.0 & 3.3 & 736.8 & 2.3 & 0.79 \\
\hline 2 & Red Kidney & $110(110-115)$ & 50.8 & 32 & 8.4 & 12.5 & 3.6 & 383.0 & 3.8 & 631.0 & 2.7 & 0.84 \\
\hline 3 & Candy & $120(120-125)$ & 97.2 & 30 & 11.2 & 14.8 & 3.0 & 288.0 & 2.9 & 821.1 & 2.1 & 0.77 \\
\hline 4 & Black Turtle & $110(110-115)$ & 89.4 & 32 & 17.2 & 8.6 & 6.2 & 318.0 & 3.2 & 171.2 & 3.2 & 0.83 \\
\hline 5 & Golden Rocky & $100(100-105)$ & 25.0 & 24 & 16.0 & 12.0 & 3.8 & 322.8 & 3.2 & 272.8 & 3.0 & 0.88 \\
\hline & $\mathrm{SE}( \pm)$ & 3.79 & 5.43 & 1.23 & 1.51 & 1.55 & 0.84 & 21.42 & 0.22 & 17.53 & 0.18 & 0.05 \\
\hline & $\mathrm{LSD}_{0.05}$ & 7.6 & 10.85 & 2.45 & 3.02 & 3.10 & 1.68 & 42.85 & 0.43 & 35.05 & 0.36 & 0.1 \\
\hline \multicolumn{13}{|c|}{ Soyabean } \\
\hline 1 & Black Jet & $130(130-135)$ & 79.8 & 32 & 24.4 & 5.1 & 2.0 & 345 & 3.4 & 273.8 & - & 0.72 \\
\hline 2 & Edamme & $130(130-135)$ & 41.0 & 20 & 27.4 & 6.1 & 2.4 & 204 & 2.0 & 380.7 & - & 0.71 \\
\hline & $\mathrm{SE}( \pm)$ & 3.76 & 4.83 & 2.01 & 3.38 & 1.23 & 0.5 & 16.46 & 0.17 & 11.34 & - & 0.04 \\
\hline & $\mathrm{LSD}_{0.05}$ & NS & 9.65 & 4.02 & NS & 2.45 & NS & 32.9 & 0.33 & 22.7 & - & NS \\
\hline \multicolumn{13}{|c|}{ Lentil } \\
\hline 1 & Crimson & $80(80-85)$ & 40 & 160 & 23.4 & 1 & 1.6 & 77 & 0.8 & 34.4 & 2.9 & 0.81 \\
\hline 2 & Essex & $85(80-85)$ & 44.2 & 188 & 16.4 & 1.2 & 1.8 & 98 & 1.0 & 41.0 & 2.3 & 0.85 \\
\hline & $\mathrm{SE}( \pm)$ & 3.9 & 4.61 & 12.25 & 4.59 & 0.3 & 0.33 & 13.44 & 0.14 & 3.86 & 0.44 & 0.04 \\
\hline & $\mathrm{LSD}_{0.05}$ & NS & NS & 24.5 & NS & NS & NS & NS & NS & NS & NS & NS \\
\hline
\end{tabular}

${ }^{1} 1000$ seed weight; ${ }^{2}$ Calculated; ${ }^{3}$ Seed weight to volume ratio; ${ }^{*}$ Commercial pea cultivar; NS Non significant.

Other weeds gradually infested the plots during mid to late season. Wheat and barley plots, with moderate to good plant density, grew well despite the weed pressure. No weeding/cultivation was done except for hilling the legumes.

Disease pressure: The most prevalent diseases encountered on at our test site included stripe and stem rusts (Puccinia spp.) and Septoria leaf blotch (Septoria spp.), with most commercial plots showing some infection starting at the end of June and continuing through mid-September. Except for "Lillian" and "Snowbird", commercial wheat cultivars were moderate to highly susceptible to Stripe rust (Table 10). Septoria leaf blotch infection was most severe on "Strongfield", 30 DAS. However stripe/stem rust were most severe on "Snowstar" and "Scarlet" followed by "Norwell" and "Strong- 
field" cultivars. "Lillian" was the most resistant commercial wheat cultivar against these diseases followed by "Snowbird".

Except for "Pacific Blue Stem", heirloom wheat cultivars displayed intermediate to high disease resistance compared with commercial cultivars (Table 10). The 2-row hulled wheats (e.g., Emmer and Einkorn series) were among the most highly resistance cultivars followed by the 6-row heirloom cultivars. Heirloom 6-row wheat cultivars "Red Bobs", "Red Fife", "Calcutta" and "Red Wheat" displayed the highest overall performance rating, 30 DAS, with "Red Fife" producing dark green leaves with the highest chlorophyll concentration index (18.45 and 16.1 in flag and 3rd leaves, respectively). However, the heirloom wheats "Red Wheat", "Cerebs", "Black Bearded", "Red Bobs" and "Calcutta" displayed high plant lodging percentage compared to the commercial cultivars (Table 10), and could be associated with the plant height as well as the location of the trial plots (the border plots in the south-west direction were observed with increased lodging due to wind).

Among the barley cultivars, UK spring barleys ("Westminster", "Decanter" and "Oxbridge") displayed the least disease severity compared with heirloom and other com-

Table 10. Performance of commercial and heirloom wheat cultivars during 2010 spring season at the UBC farm.

\begin{tabular}{|c|c|c|c|c|c|c|c|c|c|c|}
\hline \multirow{2}{*}{ Type } & \multirow{2}{*}{ Cultivar } & \multicolumn{2}{|c|}{$\begin{array}{l}\text { Chlorophyll Concentration } \\
\text { Index (CCI/71 mm²), } 30 \text { DAS }\end{array}$} & \multicolumn{4}{|c|}{$\begin{array}{l}\text { Performance Assessment/Rating*, } \\
30 \text { Days after Sowing (DAS) }\end{array}$} & \multicolumn{2}{|c|}{ Rating, 70 DAS } & \multirow{2}{*}{ Remarks } \\
\hline & & Flag Leaf & $3^{\text {rd }}$ Leaf & Greenness I & Disease $^{1}$ & Pests & Overall & Disease $^{2}$ & Lodging (\%) & \\
\hline \multirow[t]{5}{*}{ Commercial } & Lillian & 14.83 & 12.75 & 8 & 2 & 1 & 8 & 2 & 0 & $\begin{array}{l}\text { Poor germination but good } \\
\text { tillering (up to 6/plant), no } \\
\text { disease }\end{array}$ \\
\hline & Scarlet & 16.98 & 11.55 & 8 & 2 & 1 & 9 & 8 & 0 & $\begin{array}{l}\text { Good stand, vigorous but } \\
\text { diseased }\end{array}$ \\
\hline & Norwell & 15.25 & 16.55 & 8 & 2 & 1 & 9 & 7 & 0 & $\begin{array}{l}\text { Good stand, vigorous but } \\
\text { diseased }\end{array}$ \\
\hline & Snowstar & 14.03 & 14.23 & 8 & 2 & 1 & 8 & 8 & 0 & $\begin{array}{l}\text { Good stand, vigorous but } \\
\text { diseased }\end{array}$ \\
\hline & Snowbird & 13.22 & 17.17 & 8 & 2 & 1 & 9 & 4 & 10 & Good stand, low disease \\
\hline \multirow[t]{12}{*}{ Heirloom } & Red Fife & 18.45 & 16.10 & 9 & 2 & 1 & 9 & 4 & 20 & $\begin{array}{l}\text { Poor germination but good } \\
\text { tillering (up to 6/plant), low } \\
\text { disease }\end{array}$ \\
\hline & Glenn & - & - & 9 & 4 & 1 & 8 & 4 & 0 & \\
\hline & Red Wheat & - & - & 9 & 1 & 1 & 9 & 4 & 90 & $\begin{array}{l}\text { Lodging: Partial } 40 \text {, com- } \\
\text { plete } 60 \%\end{array}$ \\
\hline & Red Bobs & - & - & 9 & 1 & 1 & 10 & 5 & 50 & Partial lodging \\
\hline & Calcutta & - & - & 9 & 1 & 1 & 9 & 5 & 40 & Partial lodging \\
\hline & Cerebs & - & - & 8 & 1 & 1 & 8 & 5 & 60 & $\begin{array}{l}\text { Lodging: Partial } 40 \text {, com- } \\
\text { plete } 60 \%\end{array}$ \\
\hline & Emmer-1 & - & - & 8 & 1 & 1 & 8 & 2 & 60 & Partial lodging \\
\hline & Emmer-2 & - & - & 8 & 1 & 1 & 8 & 4 & 0 & \\
\hline & Einkorn & - & - & 8 & 1 & 1 & 8 & 1 & 0 & \\
\hline & $\begin{array}{l}\text { Black } \\
\text { Bearded }\end{array}$ & - & - & 8 & 1 & 1 & 8 & 5 & 20 & Complete lodging \\
\hline & Reward & - & - & 8 & 1 & 1 & 8 & 4 & 0 & \\
\hline & $\begin{array}{l}\text { Pacific } \\
\text { Blue Stem }\end{array}$ & - & - & 8 & 1 & 1 & 8 & 8 & 0 & \\
\hline
\end{tabular}

* Rated as 1 - 10, 1 being the lowest and 10 highest; ${ }^{1}$ Assessment for Septoria leaf blotch and scald, 30 DAS; ${ }^{2}$ Assessment for stripe rust, 70 DAS. 
mercial cultivars (Table 11). Hulless cultivars "Sunshine", "Andie" and "Ethiopian" were moderately susceptible to stripe rust disease whereas the majority of cultivars including, "CDC Gainer”, "Purple”, "Hooded”, "Jet”, “Dolma”, "Excelsior”, "Himalayan” and "Burbank" showed intermediate resistance. Commercial cultivars (e.g., "McGwire", "Copeland" and "Camus") were moderate to highly susceptible to stripe rust disease.

The barley cultivars showed variable response with respect to lodging intensity. In general, 6-row cultivars displayed greater lodging compared to 2-row cultivars (Table 11). Heirloom cultivars "Excelsior" and "Himalayan", both 6-rowed and hulless cultivars, despite of having dwarf plants, showed complete lodging (>80\%) whereas "Purple", "Dolma", "CDC Gainer" and "Burbank" displayed only partial lodging $(40 \%-60 \%)$. The 2-row UK spring barleys ("Westminster", "Decanter", "Oxbridge") and black seeded heirloom "Jet" showed no lodging. Besides the activity of six-spotted lady bird beetles, no insect damage was observed.

Root growth and nodulation: Heavy nodulation and deep penetrating root systems are desirable traits for sustainable organic farming as they have the genetic potential to fix atmospheric nitrogen and acquire water from deep in the soil profile. Through qualitative assessment, legume cultivars differed in several parameters including degree of nodulation, total root mass, and depth of root- ing. Kidney bean ("Candy”) and favabean (“Andy”, "Bell" and "Windsor") cultivars displayed good nodulation during the later stages of growth (flowering to pod setting), indicating good potential for N2 fixation. In these cultivars, 10 or more pink-red nodules were observed in the crown-root zone and elsewhere on the root system. Cultivars "Reward" (pea), "Crimson" and "Es sex" (lentil), on the other hand, produced nodule-like structures approximately 20 DAS but disappeared as the plants matured. The reason behind no or few numbers of nodules could be because no pre-plant inoculation was used and these crops were planted in new sites.

\subsection{Quality (Protein) Analysis}

Grain protein concentration (GPC) has a major impact on the end-use quality of products made from hard wheat and barley. Therefore, this trait is typically a high priority in wheat and barley improvement programs aimed at improving bread-making or malting qualities. High protein contents are required for wheat used for baking pan breads and blending, typically $>13$ percent for Canadian Western Red Spring wheat and 11 - 13 percent for UK wheat, with lower levels used for other types of bread, noodles or other food uses. In barley, low protein levels (generally below about 11\%) are required for malting, brewing and distilling, with higher levels resulting in

Table 11. Performance of commercial and heirloom barley cultivars during 2010 spring season at the UBC farm.



* Rated as 1 - 10, 1 being the lowest and 10 highest; ${ }^{1}$ Assessment for Septoria leaf blotch and scald, 30 DAS; ${ }^{2}$ Assessment for stripe rust, 70 DAS. 
reduced quality [25]. Wibberley [26], on the other hand, reported the minimum required protein content for bread wheat as $11 \%$ whereas for malting barley, it is desirable to be below $9.4 \%$.

A clear difference was observed between commercial and heirloom wheat cultivars with protein content (Table 12). Overall, heirloom cultivars showed higher protein contents with the highest level in "Einkorn" (16.2\%) followed by "Emmer-2" (15.4\%) and "Reward" (15\%). The higher protein level in the heirloom cultivars demonstrates their suitability for baking and blending purpose compared to the commercial cultivars. However, the highest yielding commercial cultivar, "Scarlet", contained the lowest protein content (9.2\%).

Except for the heirloom cultivars, no significant difference in protein content was observed between the UK spring barleys (i.e., "Oxbridge", "Westminster", and "Decanter") and other commercial cultivars (Table 12). Commercial cultivars had lower protein levels (8\% $9.6 \%)$, most appropriate for malting purposes. The heirloom black barley cultivar "Jet" had the highest protein content (13.7\%) followed by "Dolma” (13.6\%) and "Pur- ple” (12.8\%), a level desirable for livestock feed.

Variation in protein levels were observed in wheat and barley cultivars when grown under different environments and management practices. Halstead [23] reported the protein content in "Red Fife" as 9\%, 1.4\% less than observed in this experiment. Similarly, Temple [21] observed higher protein levels in "Norwell" (13.1\%) and "Scarlet" (11.5\%) when grown under different management practices in Delta, BC. Some researchers have observed that the grain protein is higher in conventional systems than in organic systems [27,28]. In contrast, Shier et al. [29] and Ryan et al. [11] reported no differences in grain protein levels of spring wheat grown in organic and conventional cropping systems, which they attributed to adequate soil nutrient levels in both systems.

\section{Conclusions}

This trial assessed performance of heirloom and commercial cultivars of wheat, barley, and several legume crops and cultivars. Above all, the tested wheat and barley cultivar performed well under organic management

Table 12. Protein content of wheat and barley cultivars grown under organic production systems during 2010 spring season at UBC farm.

\begin{tabular}{|c|c|c|c|c|c|c|c|c|c|}
\hline Type & Cultivar & $\begin{array}{c}\text { Nitrogen } \\
\text { (\%) }\end{array}$ & $\begin{array}{l}\text { Protein Content } \\
(\% \mathrm{~N} \times 5.7)\end{array}$ & End Uses & Type & Cultivar & $\begin{array}{l}\text { Nitrogen } \mathrm{F} \\
\text { (\%) }\end{array}$ & $\begin{array}{c}\text { Protein Content } \\
(\% \mathrm{~N} \times 5.8)\end{array}$ & End Uses \\
\hline \multicolumn{5}{|c|}{ WHEAT } & \multicolumn{5}{|c|}{ BARLEY } \\
\hline \multirow{6}{*}{$\begin{array}{c}\text { Commercial } \\
\text { Cultivars }\end{array}$} & Lillian & 2.01 & 11.5 & Baking/bread type & \multirow{8}{*}{$\begin{array}{l}\text { Commercial } \\
\text { Cultivars }\end{array}$} & Copeland & 1.38 & 8.0 & Malting type \\
\hline & Scarlet & 1.62 & 9.2 & Cake/pastry/malting & & McGwire & 1.49 & 8.6 & Malting type \\
\hline & Norwell & 1.81 & 10.3 & Cake/pastry/noodles & & Camus & 1.66 & 9.6 & Malt/feed \\
\hline & Snowstar & 1.74 & 9.9 & Cake/pastry & & Oxbridge & 1.39 & 8.1 & Malting type \\
\hline & Strongfield & 2.01 & 11.4 & Baking/bread type & & Westminster & 1.57 & 9.1 & Malting type \\
\hline & Snowbird & 2.08 & 11.9 & Baking/bread type & & Decanter & 1.54 & 8.9 & Malting type \\
\hline \multirow{15}{*}{$\begin{array}{l}\text { Heirloom } \\
\text { Cultivars }\end{array}$} & Red Fife & 1.82 & 10.4 & Noodles/pastry/cake & & CDC Gainer & 1.37 & 7.9 & Malting type \\
\hline & Glenn & 2.17 & 12.4 & Baking/bread type & & Sunshine & 1.62 & 9.4 & Malt/feed \\
\hline & Red Wheat & 2.49 & 14.2 & Baking/bread type & \multirow{13}{*}{$\begin{array}{l}\text { Heirloom } \\
\text { Cultivars }\end{array}$} & Purple & 2.20 & 12.8 & Feed type \\
\hline & Red Bobs & 2.32 & 13.2 & Baking/bread type & & Hooded & 2.31 & 13.4 & Feed type \\
\hline & Calcutta & 2.61 & 14.9 & Baking/bread type & & Jet & 2.36 & 13.7 & Feed type \\
\hline & Cerebs & 2.10 & 12.0 & Baking/bread type & & Dolma & 2.35 & 13.6 & Feed type \\
\hline & Sounders & 2.04 & 11.6 & Baking/bread type & & Andie & 2.11 & 12.3 & Feed type \\
\hline & Emmer-1 & 2.35 & 13.4 & Baking/bread type & & $\begin{array}{l}\text { Ethiopian } \\
\text { Hulless }\end{array}$ & 2.24 & 13.0 & Feed type \\
\hline & Emmer-2 & 2.69 & 15.4 & Baking/bread type & & Excelsior & 2.01 & 11.7 & Feed type \\
\hline & Einkorn & 2.85 & 16.2 & Baking/bread type & & Himalayan & 2.05 & 11.9 & Feed type \\
\hline & Black Bearded & 2.60 & 14.8 & Baking/bread type & & Burbank & 2.25 & 13.1 & Feed type \\
\hline & Reward & 2.64 & 15.0 & Baking/bread type & & & & & \\
\hline & Pacific Blue Stem & 1.93 & 11.0 & Baking/bread type & & & & & \\
\hline & $\mathrm{SE}( \pm)$ & & 0.45 & & & $\mathrm{SE}( \pm)$ & & 0.34 & \\
\hline & $\mathrm{LSD}_{0.05}$ & & 0.91 & & & $\mathrm{LSD}_{0.05}$ & & 0.69 & \\
\hline
\end{tabular}


systems at the UBC Farm. The following conclusions have been made and will be used to structure future trials:

- There was significant variation in yield among both heirloom wheat (2.5 to $5.2 \mathrm{t} / \mathrm{h}$ ) and barley (2.9 to 5.8 $\mathrm{t} / \mathrm{h})$ cultivars. The heirloom wheats "Reward", "Glenn", "Cerebs", "Sounders" and "Red Bobs" produced comparable grain yields $(\sim 5 \mathrm{t} / \mathrm{h})$ to the commercial cultivars with greater resistance to stripe rust disease. Hulled wheat cultivars (e.g., Emmer and Einkorn Series) displayed high resistance to stripe rust disease. Similarly, 2-row UK spring barleys (e.g., "Oxbridge", "Westminster" and "Decanter") and heirloom cultivar (e.g., "Jet”) displayed higher yield and resistance to disease compared to other commercial and the 6-row heirloom cultivars. Furthermore, hulled barleys showed strong resistance to stripe rust disease. Therefore, this trial has demonstrated the potential value of heirloom wheat and barley cultivars in terms of yield and disease resistance.

- Heirloom wheat cultivars showed higher protein levels most desirable for baking and blending purposes as compared to the commercial cultivars, with "Einkorn" displaying the highest level (16.2\%). The highest yielding commercial wheat "Scarlet" displayed the lowest protein content (9.2\%). The heirloom blackseeded barleys contained higher protein levels most suitable for animal feed. No significant difference was observed between commercial and UK spring barleys. The UK spring barleys contained lower protein levels most suitable for malting purposes.

- Among the commercial cultivars, "Scarlet" and "Norwell" appeared to be best in terms of grain yield and yield related parameters. Similarly, "Camus", "McGwire", and "Copeland" barleys showed only marginal yield differences with moderate to high susceptibility to stripe rust.

- Most of the barley cultivars matured 2 - 4 weeks earlier than the wheat cultivars. The coincidence in harvesting time (80 - 90 DAS) showed that barley can be successfully integrated with pea and lentil for combined harvesting. Hulless barley appeared to be best suited to early pea ("Snowbird", "Corgi”, "De Grace" and "Golden") and lentil ("Crimson", and "Essex") while hulled barley could be integrated with mid to late cultivars (e.g., "Reward" pea). Early wheat cultivars (e.g., "Sounders", "Reward", "Snowstar", and "Snowbird") showed possibility with late peas whereas late wheat appeared to be best suited to fava beans, kidney beans, and soyabeans. However, favabean appeared unsuitable for combined harvest as it required multiple harvests over time.

- The significant variation among heirloom cultivars for plant based parameters, disease resistance and protein content suggests the possibility of crop improvement through an accelerated breeding program. Therefore, heirloom cultivars should be considered for inclusion in cultivar-improvement programs.

- As a seed crop, soyabean, fava bean and kidney bean requires early planting (i.e., late April to early May). Also, lentil appeared to be sensitive to the low temperatures experienced during the end of the season as they produced excellent vegetative growth but contained no or only underdeveloped brown seeds making them inappropriate for late-spring planting.

- Legume crops and cultivars included in the trial did not exhibit significant nodulation, except in a few fava bean and kidney bean cultivars. This could be due to a lack of appropriate inoculums.

\section{Acknowledgements}

The authors greatly acknowledge the entire team of the Centre for Sustainable Food Systems at UBC Farm for providing organically managed land for this research. Sincere thanks are due to the collaborating farmers and institutions for providing seeds of commercial and heirloom cultivars.

\section{REFERENCES}

[1] CGC (Canada Grains Council), “Online Statistical Handbook,” The Canada Grains Council, Winnipeg, Manitoba, 2003.

[2] C. A. Campbell, R. P. Zentner, P. Basnyat, R. D. Jong, R. L. Lemke and R. L. Desjardins, "Nitrogen Mineralization under Summer Fallow and Continuous Wheat in the Semiarid Canadian Prairie,” Canadian Journal of Soil Science, Vol. 88, No. 5, 2008, pp. 681-696.

doi:10.4141/CJSS07115

[3] B. Oleson, “The Wheat Industry in Canada,” 2010. http://www.acopiadores.com/publico/atodotrigo/The Wheat Industry in Canada.pdf

[4] M. Yussefi, "Development and State of Organic Agriculture Worldwide,” In: H. Willer and M. Yussefi, Eds., The World of Organic Agriculture 2004 Statistics and Emerging Trends, IFOAM Publication, 2004.

http://www.soel.de/inhalte/publikationen/s/s_74.pdf

[5] Agriculture and Agri-Food Canada, "Organic Grains and Oilseeds,” Bi-weekly Bulletin, 2000.

http://www.agr.gc.ca/mad-dam/e/bulletine/v13e/v13n05e. pdf

[6] Statistics Canada, "Certified Organic Farming, by Provinces (2001 Census of Agriculture),” 2004. http://www.statcan.ca/english/Pgdb/agricul.htm\#farms

[7] A. Sahota, "Overview of the Global Market for Organic Food and Drink,” In: H. Willer and M. Yussefi, Eds., The World of Organic Agriculture 2004 Statistics and Emerging Trends, IFOAM Publication, 2004.

http://www.soel.de/inhalte/publikationen/s/s_74.pdf 
[8] D. Walker and A. Smith, "Evaluation of Spring Wheat, Oat and Hulless Oat and Barley Cultivars under an Organic Production Protocol,” Adaptive Research Reports, Vol. 14, 1992, pp. 257-260.

[9] M. H. Entz, R. Guilford and R. Gulden, “Crop Yield and Soil Nutrient Status on 14 Organic Farms in the Eastern Portion of the Northern Great Plains," Canadian Journal of Plant Science, Vol. 81, No. 2, 2001, pp. 351-354. doi:10.4141/P00-089

[10] J. L. Kitchen, G. K. McDonald, K. W. Shepherd, M. F. Lorimer and R. D. Graham, "Comparing Wheat Grown in South Australian Organic and Conventional Farming Systems. 1. Growth and Grain Yield,” Australian Journal of Agricultural Research, Vol. 54, No. 9, 2003, pp. 889901. doi:10.1071/AR03039

[11] M. H. Ryan, J. W. Derrick and P. R. Dann, "Grain Mineral Concentrations and Yield of Wheat Grown under Organic and Conventional Management," Journal of the Science of Food and Agriculture, Vol. 84, No. 3, 2004, pp. 207-216. doi:10.1002/jsfa.1634

[12] H. E. Mason and D. Spaner, "Competitive Ability of Wheat in Conventional and Organic Management Systems: A Review of the Literature," Canadian Journal of Plant Science, Vol. 86, No. 2, 2006, pp. 333-343. doi:10.4141/P05-051

[13] P. Barbery, "Weed Management in Organic Agriculture: Are We Addressing the Right Issues?” Weed Research, Vol. 42, No. 3, 2002, pp. 177-193. doi:10.1046/j.1365-3180.2002.00277.x

[14] R. J. French and J. E. Schultz, "Water Use Efficiency of Wheat in a Mediterranean-Type Environment. I. The Relationship between Yield, Water Used and Climate," Australian Journal of Agricultural Research, Vol. 35, No. 6, 1984, pp. 743-764. doi:10.1071/AR9840743

[15] A. A. Bomke, S. Yu and W. D. Temple, "Winter Wheat Growth and Nitrogen Demand in South Coastal British Columbia,” Canadian Journal of Soil Science, Vol. 74, No. 4, 1994, pp. 443-451. doi:10.4141/cjss94-058

[16] A. A. Bomke, W. D. Temple, G. E. Kennedy, L. Cain and M. J. Langlet, "Intensive Winter Cereal Production System for South Coastal British Columbia,” Agri-Food Regional Development Subsidiary Agreement Project \#23007, BC Ministry of Agriculture, Fisheries and Food, Victoria, 1991.

[17] S. Rempel, "Demeter's Wheats: Growing Local Food and Community with Traditional Wisdom and Heritage Wheat," Grassroots Solutions, Victoria, 2008.
[18] R. A. Bertrand, G. A. Hughes-Games and D. C. Nikkel, "Soil Management Handbook for the Lower Fraser Valley,” BC Ministry of Agriculture, Fisheries and Food, Abbotsford, 1991.

[19] J. C. Zadoks, T. T. Chang and C. F. Konzak, "A Decimal Code for the Growth Stages of Cereals," Weed Research, Vol. 14, No. 6, 1974, pp. 415-421. doi:10.1111/j.1365-3180.1974.tb01084.x

[20] D. R. Tottman, “The Decimal Code for the Growth Stages of Cereals, with Illustrations,” Annals of Applied Biology, Vol. 110, No. 2, 1987, pp. 441-454. doi:10.1111/j.1744-7348.1987.tb03275.x

[21] W. Temple, “Progress Report on Delta Farmers' Institute \& UBC Faculty of Land and Food Systems Eco-Friendly Crop Rotations Project," Faculty of Land and Food Systems, UBC, 2009.

[22] E. J. Corbin, J. Brockwell and R. R. Gault, "Nodulation Studies on Chickpea (Cicer arietinum)," Australian Journal of Experimental Agriculture and Animal Husbandry, Vol. 17, No. 84, 1977, pp. 126-134. doi:10.1071/EA9770126

[23] M. A. Halstead, "Growing Organic Winter Cereals on Vancouver Island,” Faculty of Land and Food Systems, University of British Columbia (UBC), 2007.

[24] K. K. Kidwell, G. B. Shelton, V. L. DeMacon, X. M. Chen, J. S. Kuehner, B. Baik, D. A. Engle, A. H. Carter and N. A. Bosque-Perez, "Registration of 'Kelse' Wheat," Journal of Plant Registrations, Vol. 3, No. 3, 2009, pp. 269-272. doi:10.3198/jpr2009.01.0007crc

[25] P. R. Shewry, "Improving the Protein Content and Quality of Temperate Cereals: Wheat, Barley and Rye,” In: R. M. Welch and I. Cakmak, Eds., Impacts of Agriculture on Human Health and Nutrition, Eolss Publishers, Oxford, 2006.

[26] E. J. Wibberley, “Cereal Husbandry,” Farming Press Books, Ipswich, 1989.

[27] R. T. Poutala, J. Korva and E. Varis, "Spring Wheat Cultivar Performance in Ecological and Conventional Cropping Systems,” Journal of Sustainable Agriculture, Vol. 3, No. 3-4, 1993, pp. 63-83. doi:10.1300/J064v03n03 05

[28] W. Starling and M. C. Richards, "Quality of Commercial Samples of Organically Grown Wheat,” Annals of Applied Biology, Vol. 36, 1993, pp. 205-209.

[29] N. W. Shier, J. Kelman and J. W. Dunson, “A Comparison of Crude Protein, Moisture, Ash and Crop Yield between Organic and Conventionally Grown Wheat,” Nutrition Reports International, Vol. 30, 1984, pp. 71-76. 